\title{
Late Oligocene calcareous nannofossils from Albanian- Thessalian intramontane basin (Bozdovec Section, Albania) - a quantitative approach
}

\author{
Mădălina-Elena KALLANXHI ${ }^{*}$, Stjepan ĆORIĆ ${ }^{2}$ \& Arben KOÇIU ${ }^{2}$ \\ ${ }^{1}$ Babeş-Bolyai University, Department of Geology, Kogălniceanu 1, 400084 Cluj-Napoca, Romania \\ ${ }^{2}$ Geological Survey of Austria, Neulinggasse 38, A-1030 Vienna, Austria
}

Received: September 2015; accepted December 2015

Available online 4 January 2016

DOI: http://dx.doi.org/10.5038/1937-8602.60.1.1286

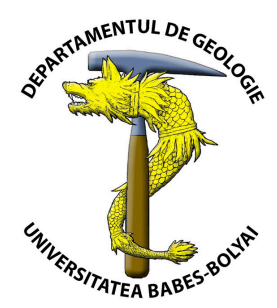

\begin{abstract}
Quantitative and semi-quantitative analyses of calcareous nannofossils were performed on samples collected from Bozdovec Section (Albanian-Thessalian intramontane basin, Albania). The calcareous nannofossil assemblages are dominated by: small reticulofenestrids, Cycligargolithus floridanus, Coccolithus pelagicus, Sphenolithus spp., Reticulofenestra scrippsae, Helicosphaera spp., Clausicoccus spp., Reticulofenestra bisecta, Cycligargolithus abisectus. Biostratigraphically, the studied outcrop is assigned to the Late Oligocene NP25 - Sphenolithus ciperoensis Zone. In the Mediterranean area, this interval can be correlated with the MNP25a - Sphenolithus ciperoensis Zone, while according to the zonation for low to middle latitudes the investigated material would belong to the CNO5 Sphenolithus ciperoensis TZ. High amounts of small reticulofenestrids and sphenoliths point to warm well stratified paleoenvironment.
\end{abstract}

Keywords: Late Oligocene, Mediterranean area, Albanian-Thessalian intramontane basin, biostratigraphy, calcareous nannofossils, statistics.

\section{INTRODUCTION}

The Albanian-Thessalian intramontane basin (Fig. 1) was formed after the main folding of the Krasta (= Pindos) Zone and represents a narrow and elongated marine basin, filled with molasse-type deposits, which extends from southeast (SE) to northwest (NW), from Thessaly in Greece up to Devolli, Korça, Gora and Mokra regions and further to the Librazhdi and Burrel basins in Albania. Its substratum is represented by the deposits of Mirdita and Korabi zones (Papa and Pashko, 1966; Pashko et al., 1973; Pashko, 1977; Meço and Aliaj, 2000).

Bourcart (1922) named this part of the basin referring to the Mesohellenic Basin (Brunn, 1956), and later Pashko et al. (1973) named it Korça Basin.

Pashko (1996) describes three distinct sedimentary sequences of molasse-type deposits, starting with the first cycle which was deposited during Middle Eocene, followed by the second one which comprises sequences from Middle Oligocene up to Lower Miocene, while the third cycle is Burdigalian to Langhian.

The second molasses cycle is the most important of the Albanian-Thessalian intramontane basin and it overlies transgressivelly Lutetian deposits and, in some regions, the ultramafic basement of Mirdita Zone, showing a distinct angular unconformity (Papa and Pashko, 1966; Pashko, 1977, 1981, 1996).

Data on the biostratigraphy of the molasse-type deposits of the Albanian-Thessalian intramontane basin were published on: mollusks and corals (Bourcart, 1922, 1925), mollusks and foraminifers (Pashko et al., 1973; Pashko, 1977, 1986, 1987), foraminifera, mollusks and corals (Petro and Dodona, 1976), foraminifera, mollusks, palynomorphs and nannoplankton (Kumati et al., 1997), mollusks (Philippson and Oppenheim, 1894; Marku, 2000), fossil plants (Kleinholter, 2004) etc.

The first studies in Albania based on calcareous nannofossils and their application in biostratigraphy, were done by Islami and Prençi (1983), Islami and Çobo (1985), Çobo (1986, 1992, 1996), Vathi and Budri (1986), Dalipi and Çobo (1989), Vathi $(1985,1987,1989,1998)$ etc.

The purpose of this study is to bring new information on the calcareous nannofossils biostratigraphy and paleoecology of Upper Oligocene molasse-type deposits in the region.

\section{GEOLOGICAL SETTINGS}

The stratigraphical sequence of Middle Oligocene - Lower Miocene molasse deposits in Morava Mountain (Fig. 2), on the eastern margin of Albanian-Thessalian Basin, includes following formations according to Pashko (1996): the basal conglomerates of the Mborja-Dishnica Formation, the coal bearing Drenova Formation, the Drenica Formation (=Koralori), marlstones of the Chama Formation, the Plasa Formation, the Bozdovec Formation and the Guri i Capit Formation.

The Late Oligocene in the Korça Basin is represented by typical marine and lagoonal deposits overlaying conformably the Middle Oligocene and starting at the base with marlstones of the 


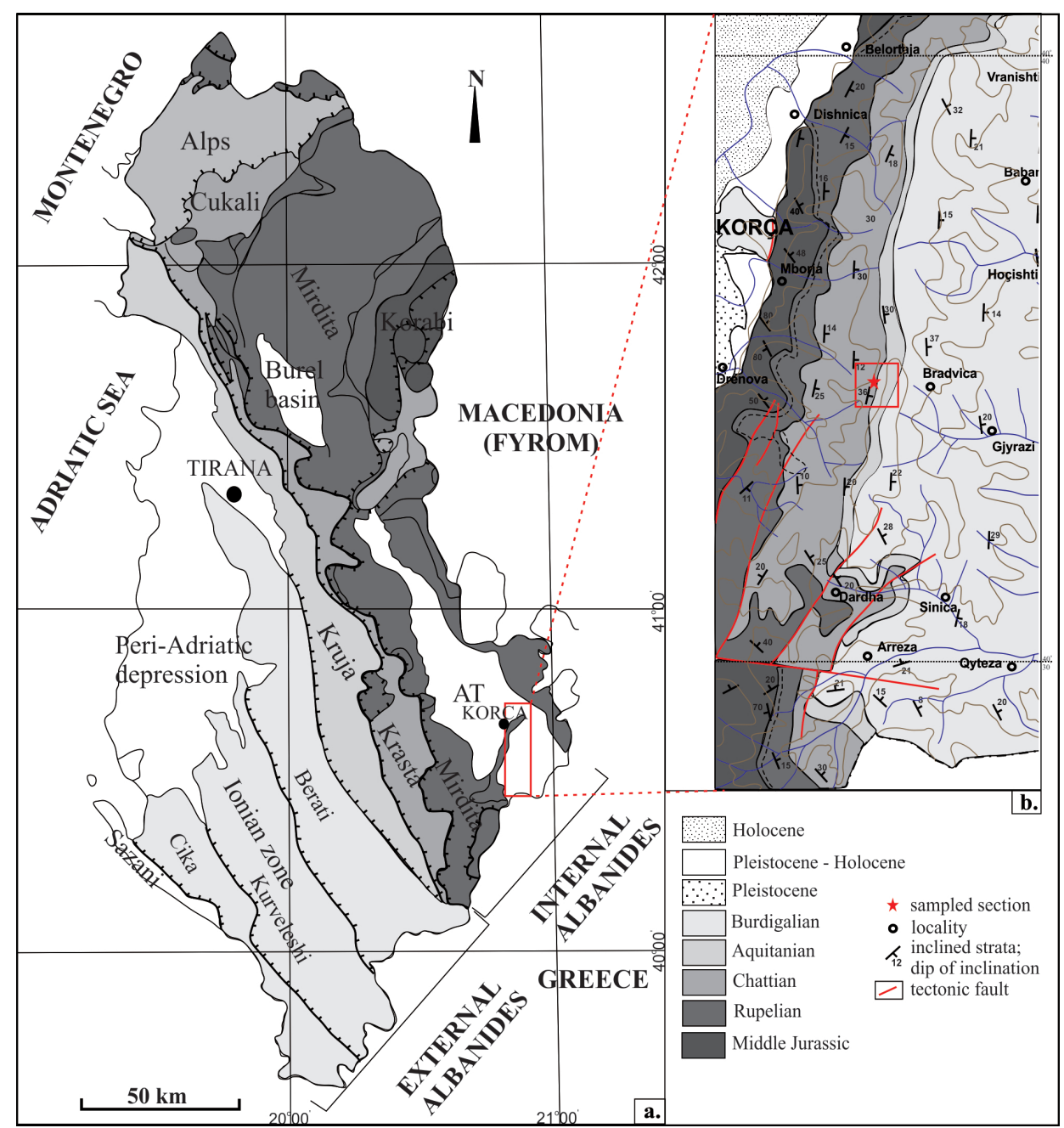

Fig. 1. a) Tectonic map of Albanides; b) Geological map of the studied area 1:200000 (after Xhomo et al., 2002, modified).

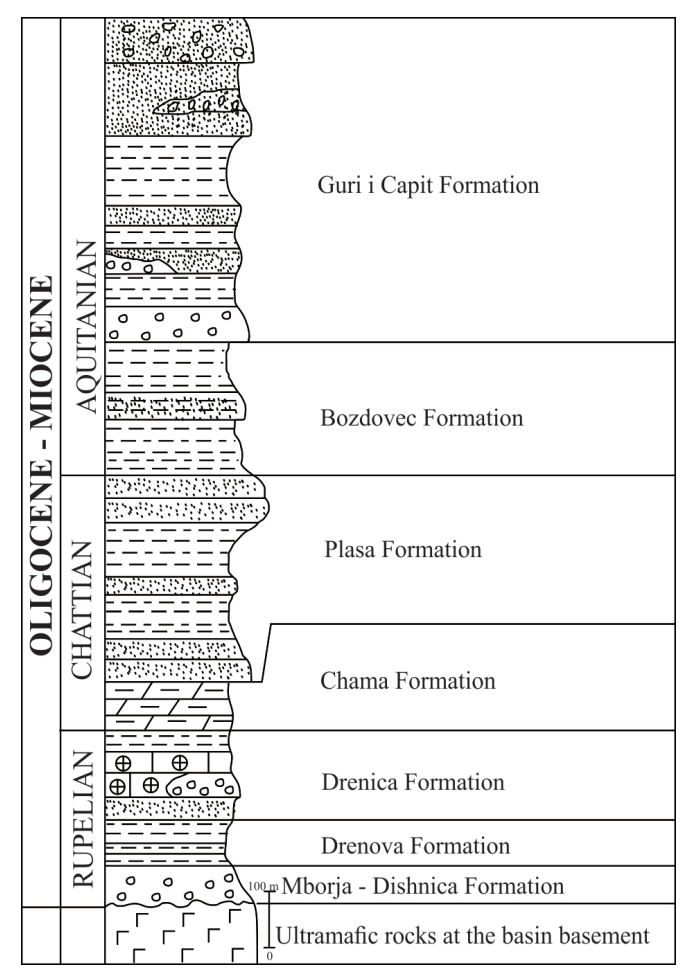

Fig. 2. a) Stratigraphical section of the Middle Oligocene - Lower Miocene mollase in Morava Mountain, Albanian-Thessalian intramontane basin (after Pashko, 1996, modified). 
Chama Formation composed by carbonatic clays, marlstones and less siltstones with rich foraminifera and mollusks assemblages, followed by the Plasa Formation, represented by massive sandstones with plants, foraminifera and mollusks (Pashko, 1977; Kumati et al. 1997) etc. The Bozdovec Formation consists of marlstones, siltstones and sandstones strata alternations containing rich foraminifera and mollusks assemblages, and represents the base of the Aquitanian stage, which was constrained mainly using macrofauna content (Pashko, 1996).

\section{MATERIAL AND METHODS}

The studied outcrop is located in the eastern part of the Korça Basin (N40³4'48.374", E02050'9.659') and lithologically comprises a continuous marly succession, alternating in the middle-upper part with marly siltstones and fine to medium grained sandstone layers.

A number of 103 samples were collected from marlstones and calcareous siltstones (Fig. 3), at a sampling distance of $0.50-1 \mathrm{~m}$. For all samples, smear slides were prepared according to standard smear slide technique (Bown and Young, 1998). Quantitative analyses were performed on 73 samples, by counting at least 300 specimens per sample, and semi-quantitative analyses were performed on 29 samples, by counting at least 100 specimens per sample. On one sample only qualitative observations were possible due to low number of the encountered nannofossils.

The nannofossil abundance was assessed as follows: $\mathrm{C}$ - common ( $>10$ specimens / FOV - field of view), F - few (1-10 specimens / FOV), R - rare (1-10 specimens /10 FOV); VR - very rare (when 1 specimen is present in more than 10 FOV). Additionally, 100 FOV were checked for rare taxa. The preservation was noted with: $\mathrm{M}$ - moderate and $\mathrm{P}$ - poor.

The software package PAST (PAleontological STatistics) was used for statistics interpretation (Hammer et al., 2001). Multivariate Cluster Analysis by Ward's method was used to group the samples into clusters, while the Principal Components Analysis (PCA) shows the grouping of samples into clusters according to environment variables and species environmental demands. The zonation scheme used in this study is that of Martini (1971), based on FO - First Occurrence and LO - Last Occurrence of index species.

Photographs were captured with a Canon Powershot A630 digital camera, under cross-polarized light (XPL) and parallel light (BF).

\section{RESULTS}

The examined material contains moderately to poorly preserved, diverse calcareous nannofossil assemblages, which are generally represented in order of abundance by: Reticulofenestra minuta, Cyclicargolithus floridanus, Coccolithus pelagicus, Reticulofenestra sp. (size 3-4.5 $\mu \mathrm{m}$ ), Sphenolithus moriformis, Reticulofenestra scrippsae, Sphenolithus ciperoensis, Cyclicargolithus abisectus, Reticulofenestra cf. minutula, Reticulofenestra bisecta, Sphenolithus conicus, Reticulofenestra dictyoda, Sphenolithus dissimilis, Helicosphaera euphratis, Discoaster deflandrei, Clausicoccus fenestratus, Zygrhablithus bijugatus, Clausicoccus subdistichus, Coccolithus miopelagicus.

A total number of 127 calcareous nannofossil species was identified, from which 60 species are autochthonous, 44 are interpreted as reworked from lower stages of Paleogene Early Oligocene and 23 species are reworked from Cretaceous deposits. The reworked taxa are diverse, but their abundance is very low. The total number of species and the number of counted specimens is given in Appendix 1.

The Reticulofenestra genus (P1. I, Figs. 6, 13, 16-17, $19,20-21,26,32 a)$ is the most abundant in the investigated material. The most common species are: Reticulofenestra minuta, Cycligargolithus floridanus, Reticulofenestra sp. (small reticulofenestrids 3-4.5 $\mu \mathrm{m}$, with closed central area), $R$. scrippsae, $R$. cf. minutula, $R$. bisecta, Cycligargolithus abisectus (in sizes $<10 \mu \mathrm{m}$ and $>10 \mu \mathrm{m}$ ), $R$. dictyoda etc.

From the Coccolithaceae family (Pl. I, Figs. 9-12, 18), the most abundant species is Coccolithus pelagicus, followed by Clausicoccus spp. (Clausicoccus fenestratus and C. subdistichus). Rare and irregularly distribution have Coccolithus miopelagicus, C. eopelagicus and Hughesius tasmaniae.

The Sphenolithus genus (Pl. I, Figs. 8a, 22, 23-24, $27-28,33-34,35-36)$ reach amounts up to $20 \%$ in some samples, being represented by species like: Sphenolithus moriformis, S. ciperoensis, S. conicus, S. dissimilis, S. cf. delphix, S. cf. calyculus and Sphenolithus sp. The marker species $S$. ciperoensis is well established and present through the entire profile.

The Helicosphaera genus (Pl. I, Figs. 1, 2, 3-4, 5, 32b) is rare, but continuous and the most common species are: Helicosphaera euphratis, $H$. obliqua, $H$. recta, $H$. intermedia, $H$. perch-nielseniae, H. bramlettei, $H$. cf. carteri etc.

Discoaster spp. (Discoaster deflandrei and Discoaster sp.) and the species Zyghrablithus bijugatus (subsp. bijugatus) have rare, but more or less continuous occurrence. The forms with tall spines $(>12 \mu \mathrm{m})$ were assigned to $Z$. bijugatus subsp. maximus.

From the Pontosphaeraceae family, the most common species are: Pontosphaera multipora, Pontosphaera sp. and Pontosphaera cf. enormis, the last one appearing in 26 samples.

Very rare is Triquetrorhabdulus carinatus (Pl. I, Figs. 1415), which appears in only 11 samples and Thoracosphaera spp. Ilselithina fusa is also very rare, but present in 11 samples.

The most common reworked species are: Toweius rotundus, Toweius selandianus, Prinsius bisulcus, Prinsius dimorphosus, Prinsius martinii, Coccolithus bownii, Coccolithus foraminis, Chiasmolithus spp., Ericsonia spp., Watznaueria barnesiae, Micula staurophora, Microrhabdulus sp., Quadrum sp. etc.

The abundance patterns of some mentioned species and taxonomical groups can be observed in figure 4 .

\section{Biostratigraphy}

Biostratigraphically, the studied material ranges up to the late Chattian - Sphenolithus ciperoensis Zone (NP25) of Martini (1971). The attribution to NP25 is supported also by the absence of the marker species Sphenolithus distentus (with LO in top of NP24 Sphenolithus distentus Zone of Martini, 1971).

In terms of the Mediterranean Zonation, according to Fornaciari and Rio (1996), the studied interval would fall within MNP25a - Sphenolithus ciperoensis Zone, defined 


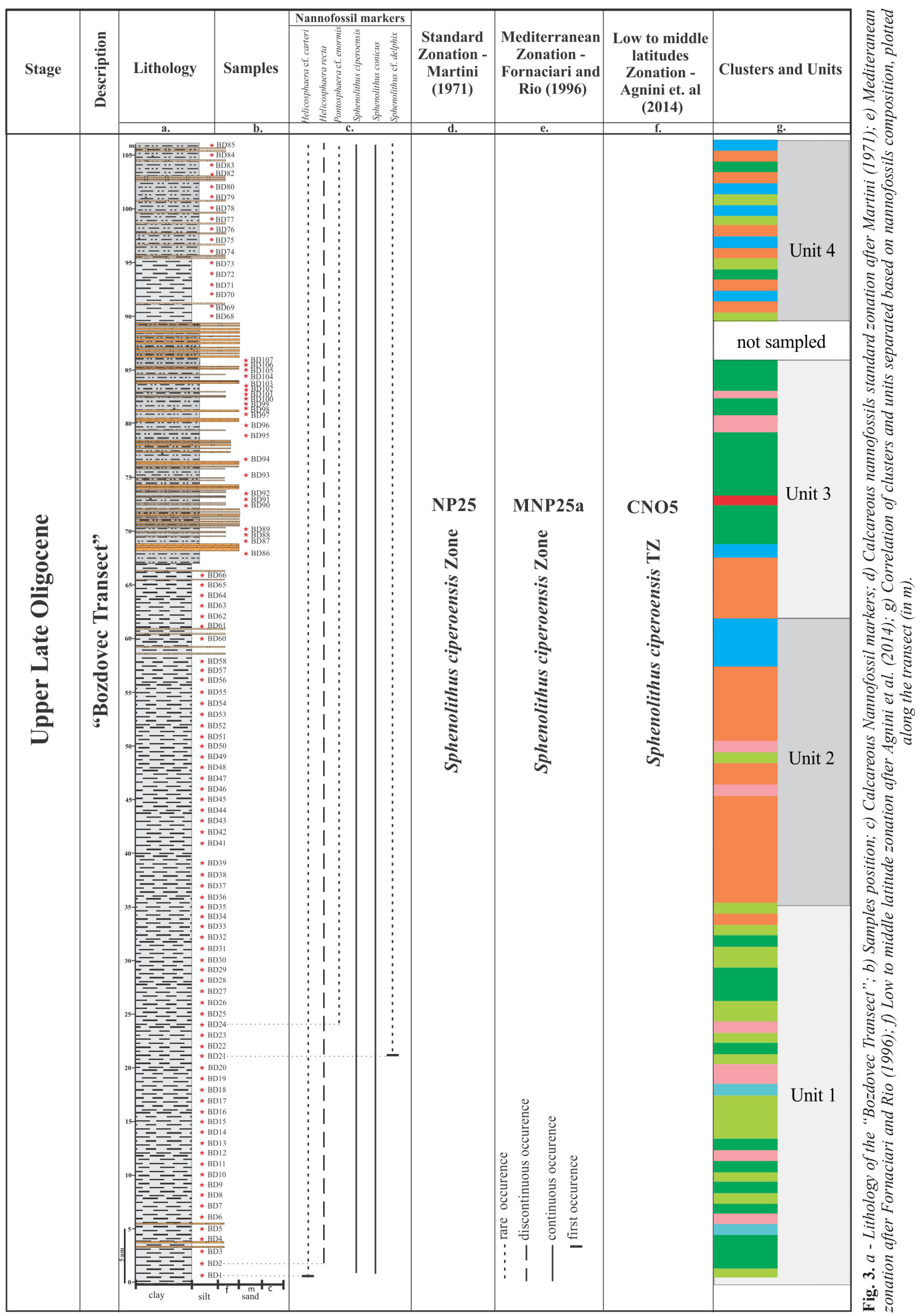




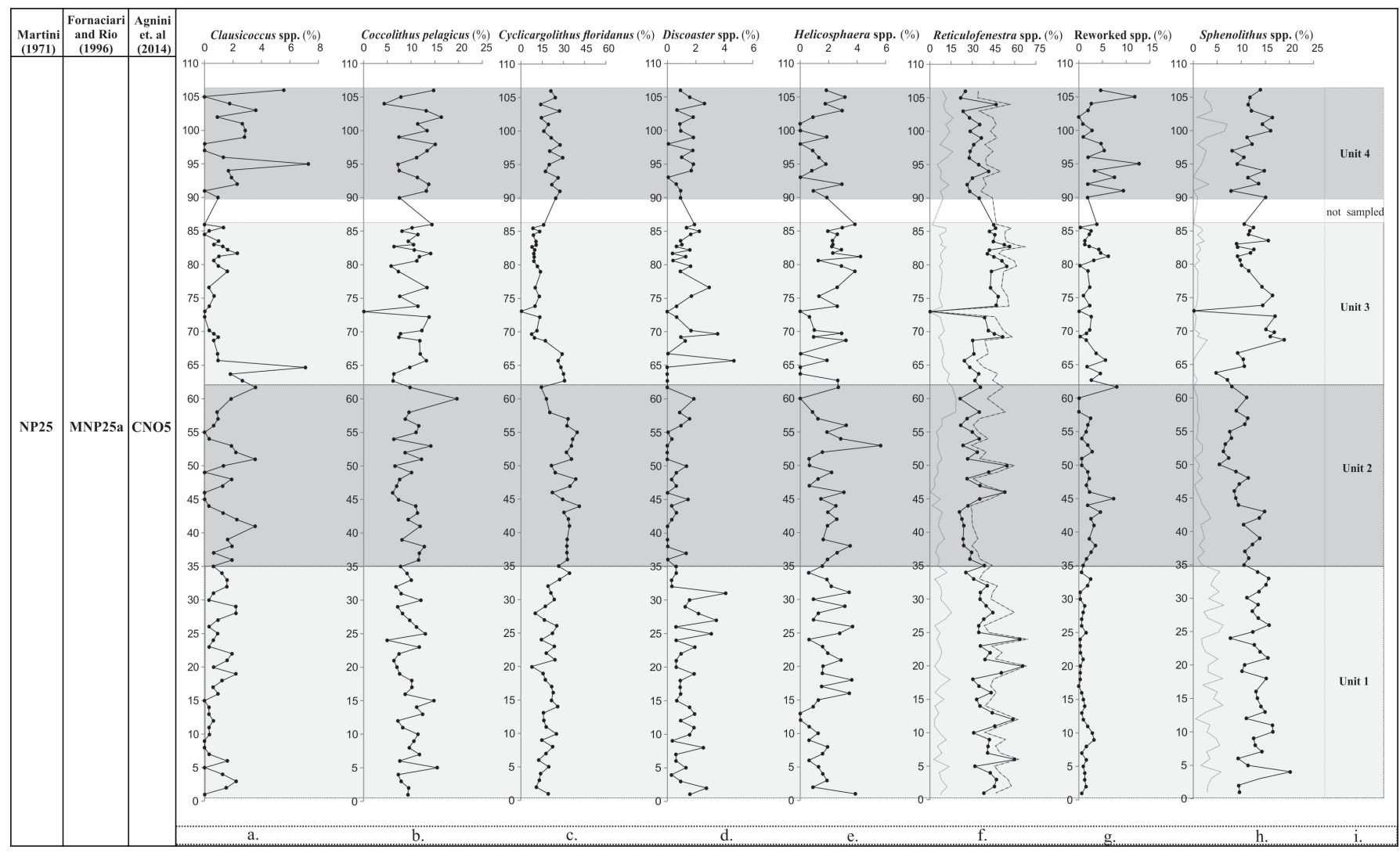

Fig. 4. Abundance patterns (•-•) of the most important species and taxonomical groups plotted along the standard zonations of Martini (1971), Fornaciari and Rio (1996), Agnini et al. (2014) and along the sampling interval (in m): $a$. Clausicoccus spp.; b. Coccolithus pelagicus; c. Cyclicargolithus floridanus; $d$. Discoaster spp.; e. Helicosphaera spp.; f. Reticulofenestra spp. all (-•-) vs. Reticulofenestra small gr. and Reticulofenestra spp. (size >5) (…); g. Reworked spp.; h. Sphenolithus spp. vs. Sphenolithus ciperoensis (…); i. Units (see description in text).

by the LO of Sphenolithus distentus at the base and LO of Sphenolithus ciperoensis at the top. The continuous presence of the marker species Sphenolithus ciperoensis in the transect, allowed correlation also with the CNO5 Sphenolithus ciperoensis TZ (Top Zone) of Agnini et al. (2014), defined by the Top of Sphenolithus predistentus at the base and Top of Sphenolithus ciperoensis at the top.

\section{Paleoecology and Multivariate Statistics}

The following species and taxonomical groups were considered for paleoecological interpretation and statistics: Reticulofenestra small group, Cycligargolithus floridanus, Coccolithus pelagicus, Sphenolithus spp., Helicosphaera spp. and Reticulofenestra spp. (>5 $4 \mathrm{~m})$.

Reticulofenestrids are the most abundant in the investigated material, reaching amounts up to $70 \%$ in some samples. They were separated into two groups based on the coccolith size: the small reticulofenestrids group (size $<4.5$ $\mu \mathrm{m}$ ) and the Reticulofenestra spp. group (medium to very large sized specimens $>5 \mu \mathrm{m}$ ). The small reticulofenestrids group occurs continuously and in high amounts through the whole profile and includes Reticulofenestra minuta, Reticulofenestra sp. (small species 3-4.5 $\mu \mathrm{m}$, with closed central area) and Reticulofenestra cf. minutula.

Cyclicargolithus floridanus is a major component of the assemblages, with an average participation of $21 \%$ from total (values in samples between $8 \%$ and $41 \%$ ).

Coccolithus pelagicus appears continuously in the investigated material and represents about $10 \%$ of the total calcareous nannofossil assemblage (with values from $5 \%$ to $20 \%$ ).

Sphenoliths are a major component of the assemblage ( $12 \%$ of the total), being continuously present through the whole section.

Helicoliths are species associated to surface waters and nearshore environments (Bukry et al., 1971; Krhovský et al., 1992) and, according to Perch-Nielsen (1985), are common in upwelling conditions. They are rare, but more or less continuously present and represent $2 \%$ of total nannofossil assemblage.

Pontosphaera genus is rare and has discontinuous appearance. In general, this genus is associated with shallow marine environments and decreased salinity (Krhovský et al., 1992; Nagymarosy and Voroniná, 1992).

Discoaster genus is very rare and reaches amounts up to $4 \%$. It is confined to deep marine, oligotrophic environments, with warm waters and more stable conditions (Lohman and Carlson, 1981; Aubry, 1992; Young, 1998).

In summary, the nannofossil assemblages indicate predominantly shallow, nearshore marine environments, relatively stable, and minor eutrophic to oligotrophic changes.

Multivariate Hierarchical Clustering as shown in figure 5 and Principal Components Analysis (Fig. 6) grouped the samples according to their composition similarities. Five clusters were identified as follows:

- Cluster 1 - comprises 11 samples with highest content of Reticulofenestra small gr. (50 to 65\%), followed by Cyclicargolithus. floridanus (7 to $22 \%$ ) and less Coccolithus pelagicus (up to $11 \%$ ). 


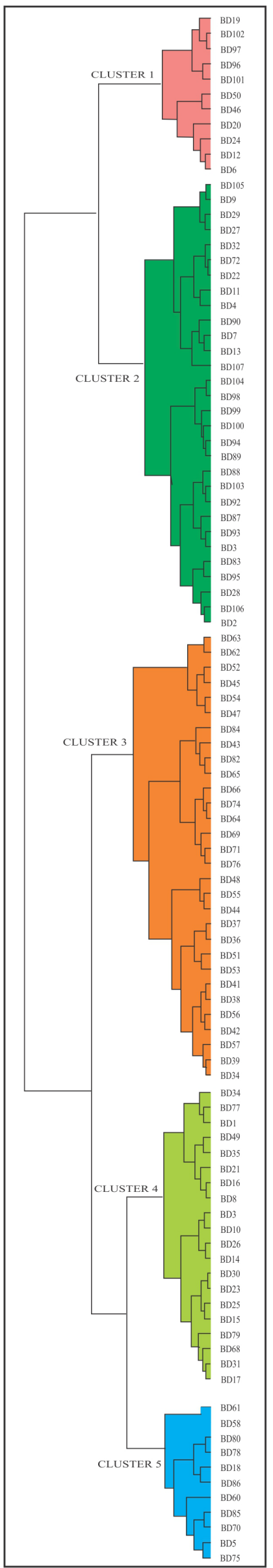

Fig. 5. Multivariate Clustering by Ward's Method.
- Cluster 2 - comprises 29 samples with high amount of Reticulofenestra small gr. (38 to 51\%), followed by Sphenolithus spp. (9 to 20\%), less Cyclicargolithus floridanus ( 8 to $19 \%$ ) and Coccolithus pelagicus (4 to $14 \%$ ).

- Cluster 3 - has 30 samples characterized by highest amount of Cyclicargolithus floridanus (30 to 41\%), followed by Reticulofenestra small gr. (up to 35\%), Coccolithus pelagicus (up to 14\%), Sphenolithus spp. (up to 15\%).

- Cluster 4 - has 21 samples with high amount of Reticulofenestra small gr. (31 to 43\%), Cy. floridanus (19 to $27 \%$ ), Sphenolithus spp. (9 to $17 \%$ ), C. pelagicus (6 to $15 \%$ ).

- Cluster 5 - has 11 samples with high amount of Reticulofenestra small gr. (up to 35\%), Cy. floridanus (up to $22 \%$ ), highest amount of $C$. pelagicus (10 to $19 \%$ ) and

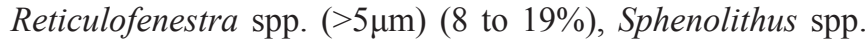
(8 to $19 \%$ ).

\section{DISCUSSIONS}

\section{Biostratigraphy}

A special discussion will focus on the Sphenolithus genus, due to its biostratigraphical importance for the subdivision of the upper Early to Late Oligocene interval, based on presence/ absence of Sphenolithus predistentus, S. distentus and $S$. ciperoensis lineage, according to the Martini (1971) zonation.

The Sphenolithus ciperoensis Zone of Martini (1971) was previously described from Upper Oligocene deposits from other sections in the Albanian-Thessalian intramontane basin (Kumati et. al., 1997), also in other areas in Albania (Vathi, 1998). The continuous presence of $S$. ciperoensis (P1. I, Figs. 23-24), index species, and the presence of other sphenoliths like Sphenolithus conicus, S. dissimilis, S. calyculus, all with FO at the base of NP25, are supporting our attribution to this zone. The nannofossil zone NP24 was not found in this section.

In 19 samples the rare appearances of the important marker species Sphenolithus cf. delphix (P1. I, Figs. 27-28, 33-34) is noticed, which raise a question mark regarding the presence of the Sphenolithus delphix Subzone MNN1b of Fornaciari and Rio (1996), described from the Mediterranean Zonation. First appearance of Sphenolithus cf. delphix is noticed at $21 \mathrm{~m}$, in sample BD21.

The synchronicity of the nannofossil events present below and above the Oligocene/Miocene boundary are formally described from Lemme-Carrosio Section in Northern Italy, were the FO of Sphenolithus delphix is placed within NP25 Zone, being continued upwards with FO and LO of Sphenolithus capricornutus and LO of Sphenolithus delphix. Correlation of these events was done with the ODP Site 522 from the South Atlantic Ocean (Raffi, 1999; Shackleton et al., 2000). Sphenolithus delphix and S. capricornutus are reported to be distributed from the Late Oligocene to the Early Miocene (Perch-Nielsen, 1985). The LO of Sphenolithus delphix is considered by Aubry and Villa (1996), as being the only event that marks the Oligocene/Miocene boundary. Despite the presence of $S$. cf. delphix, the boundary position in this outcrop cannot be assigned, due mainly to the absence of Sphenolithus capricornutus.

Sphenolithus conicus (P1. I, Figs. 35-36) is present in the studied samples, from the first sample (BD1), and has a continuous distribution. Perch-Nielsen (1985) reports this 


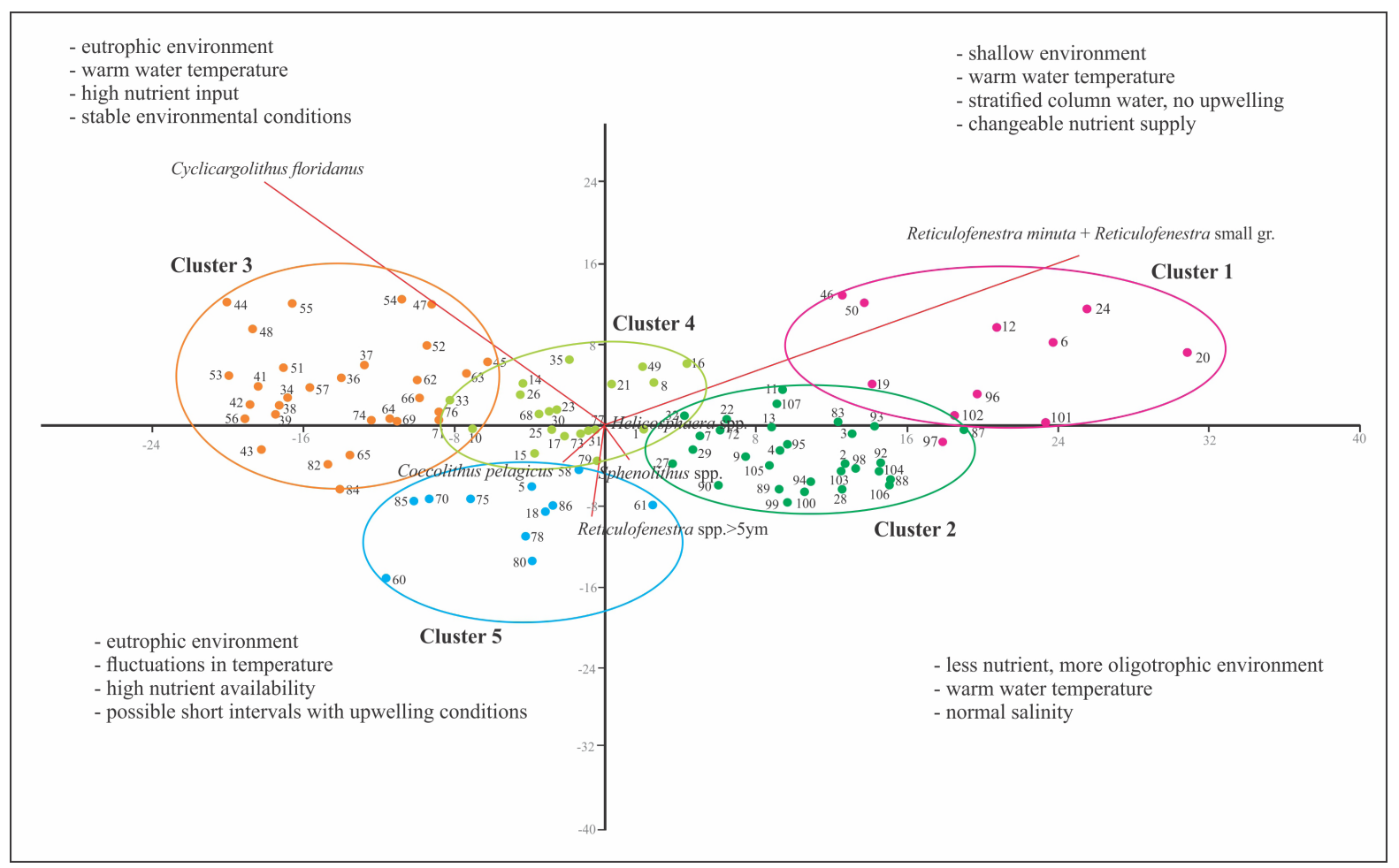

Fig. 6. Principal Components Analysis showing the clusters distribution according to environmental variables (Davis, 1986; Harper, 1999).

species from the Early Miocene NN1-NN3 Zones. In the Western Equatorial Indian Ocean, Fornaciari et al. (1990) recorded $S$. conicus from CN1-CN2 Zones of Okada and Bukry (1980).

During the past decades several nannofossil events (e.g. LO of Sphenolithus ciperoensis, LO of Helicosphaera recta, LO of Zygrhablithus bijugatus, LO of Reticulofenestra bisectus) were used by different authors (Martini, 1971; Martini and Müller, 1975; Müller, 1976; Okada and Bukry, 1980; Berggren et al., 1995; Fornaciari and Rio, 1996), to define the Oligocene/Miocene boundary, but not all proved to be reliable.

The LO of Helicosphaera recta (P1. I, Figs. 3-4) proved not to be a reliable marker for the Oligocene/Miocene boundary, its range going up to base of NN2 - Discoater drugii Zone of Martini (1971) in some areas. Investigations from the Indian Ocean, by Bizon and Müller (1979), found the LO of Clausicoccus fenestratus (P1. I, Fig. 10) to be together with the LO of Sphenolithus ciperoensis, Dictyococcites bisectus and $H$. recta, near the Oligocene/Miocene boundary.

Some authors (Martini and Müller, 1975; Müller, 1976) proposed the LO of Zygrhablithus bijugatus (P1. I, Figs. 6, $8 \mathrm{~b}$ ) to approximate the top of NP25 and thus, the Oligocene/ Miocene boundary in nearshore environments. This species is not common in deep-marine sediments and its abundance decreases with increasing of water depth.

Rare and discontinuous presence of Helicosphaera cf. carteri is recorded in only 9 samples. Vathi (1998) uses the presence of $H$. carteri to establish the Oligocene/Miocene boundary in other regions in Albania (Ionian Zone). His investigations mention this species as being present in the Sphenolithus predistentus and S. distentus zones of Martini (1971), missing in S. ciperoensis Zone and reappearing in the Early Miocene within his Helicosphaera carteri Zone.
Our data are in agreement with those of Holcová (2005), who report the FAD of Helicosphaera carteri within NP25 Zone, from material collected from several boreholes from the northern part of Buda Basin (South Slovak Depression, Central Paratethys). Other authors describe the presence of H. carteri from NN1-NN2 biozones (Perch-Nielsen, 1985; Mărunţeanu, 1992; Krhovský et al., 1995; Aubry and Villa, 1996).

Other important species is Pontosphaera cf. enormis (Pl. I, Fig. 25), which appears in 26 samples and which was used to define the base of NP25 in areas with poor sea way connection (Martini, 1981).

\section{Paleoecology and Multivariate Statistics}

Regarding the paleoecology, as a general trend, the presence in high amounts of Reticulofenestra minuta, a species usually abundant along continental margins (Haq, 1980), would suggest stable marine conditions, with warm, well stratified water column. Gartner et al. (1983) suggest that the changes in $R$. minuta abundance are connected with nutrient availability, while according to Kameo (2002) the Reticulofenestra spp. small are eutrophic species. According to Wade and Bown (2006), R. minuta can adapt to a wide range of salinities, from normal to hypersaline environments.

Holcová (2005), reports from the upper NP25 from the northern part of Buda Basin, an acme event of small reticulofenestrids, considered to be an ecostratigraphical event.

Abundant small reticulofenestrids ( $R$. minuta) were documented from Lower - Middle Miocene of the Central Paratethys by Ćorić and Rögl (2004), Tomanová Petrová and Švábenická (2006), Ćorić and Hohennegger (2008) etc. Ćorić and Rögl (2004) suggest that they are abundant in warm waters without upwelling conditions. 
Krhovský et al. (1992) suggest that Cyclicargolithus floridanus and Cyclicargolithus abisectus, are more frequent in near-shore environments. According to Shcherbinina (2010) Cyclicargolithus floridanus and Reticulofenestra are eurytopic genera, which adapt to a wide range of environmental conditions. Cyclicargolithus floridanus is considered a species which prefers eutrophic conditions (Aubry, 1992; Krhovský et al., 1992; Villa et al., 2008).

Coccolithus pelagicus is a cold water species, abundant between $-1.5^{\circ} \mathrm{C}$ to $+15^{\circ} \mathrm{C}$ (Okada and MacIntyre, 1979 ; Winter et al., 1994), and more common in eutrophic environments, surface waters with high nutrient input and upwelling areas (Rahman and Roth, 1990).

Regarding the paleoecology of Sphenolithus genus which is quite abundant in the investigated material, it is considered by Perch-Nielsen (1985) to be common in warm, shallow waters and oligotrophic environments.

Based on nannofossils quantitative analyses and the ecological preferences of the most abundant species, the palaeoenvironmental evolution of the investigated outcrop was distinguished. The five clusters identified by the means of statistical methods and their distribution along the transect, are given below. According to cluster analyses, four units divide the transect from base to the top as follows (Fig. 4):

Unit 1 - Comprises the interval from 0 to $35 \mathrm{~m}$, being occupied by samples belonging to Clusters 2 and 4 . These clusters suggest relatively stable paleoenvironmental conditions, due to the presence of high amounts of small reticulofenestrids and Cyclicargolithus floridanus, with fluctuations in nutrient input as shown by Cluster 2 (with higher amounts of sphenoliths, meaning less nutrient input and less eutrophic environment) and Cluster 4 (high nutrient input and well established eutrophic conditions). Six samples of Cluster 1 show similar trends, except the two samples of Cluster 5, at $5 \mathrm{~m}$ and $18 \mathrm{~m}$, which suggest a slight deviation from these conditions, maybe some short temperature decrease.

Unit 2 - The interval from 35 to $62 \mathrm{~m}$ is dominated by Cluster 3, characterized by highest amount of Cyclicargolithus floridanus and high percentages of small reticulofenestrids. High percentages of Cy. floridanus point to the stable conditions without changes in the nutrient supply.

Unit 3 - The interval from 62 to $85 \mathrm{~m}$, dominated by samples belonging to Cluster 2, is characterized by high percentages of small reticulofenestrids, sphenoliths and less Cy. floridanus and represents the transition interval from the stable conditions of Unit 2 to the unstable environment of Unit 4. Lower percentages of $C y$. floridanus point to changes in the nutrient supply.

Unit 4 - The interval from 89 to $106 \mathrm{~m}$ is characterized by equal presence of all clusters, suggesting the most unstable environmental conditions. In this part a decrease in nannofloral abundance is noticed, but no sign of changed salinity. The diversity remains the same. This can be the result of changing of sedimentation conditions within the basin, due to upwelling regime, dynamics in nutrient supply. These changes are probably caused by regression events and reflect also changes in lithology.

Based on species abundance patterns, theirpalaeoecological demands, statistical distribution along the studied outcrop, the recorded shifts in species abundance between the clusters, the general conclusion is that during the deposition of these deposits, a warm stable marine environment was present, sometimes more eutrophic conditions, high nutrient availability (higher amounts of Cyclicargolithus floridanus), shallow, well stratified column water (small reticulofenestrids). Although, short periods of decreased temperature (highest \% of Coccolithus pelagicus), fluctuations in nutrient availability and less eutrophic environment (higher content of Sphenolithus spp. which prefers more oligotrophic conditions) can be documented at some levels along the profile and more in last described unit.

\section{CONCLUSIONS}

First time, statistics based on calcareous nannofossils in this part of Albanian-Thessalian intramontane basin was applied.

Biostratigraphically, correlation of the investigated outcrop to the standard nannofossil Zone NP25, to the Mediterranean Zone MNP25a and to the new zonation for low to middle latitudes, was possible, and it is based on to the absence of species Sphenolithus distentus and continuous presence of index species Sphenolithus ciperoensis. The biostratigraphical events identified in NP25 - Sphenolithus ciperoensis Zone are: FO of Sphenolithus cf. delphix and FO of Helicosphaera cf. carteri.

Paleoenvironmental reconstruction of the "Bozdovec Transect" (Albanian-Thessalian intramontane basin) was done based on quantitative and semi-quantitative analyses of the selected nannofossils taxa and groups. High amounts of small reticulofenesdrids and of Sphenolithus genus were recorded, suggesting similar paleoconditions with other areas of the Central Paratethys domain.

No changes in calcareous nannofossils diversity were observed, only decrease in abundance in the upper part of the profile.

The calcareous nannofossils suggest warm, shallow and relatively stable marine conditions, going along with the general warm climate trend which dominated the upper part of the Late Oligocene - Early Miocene in Mediteranean and Central Paratethys domains.

Acknowledgements. This work was possible due to the financial support of the Sectorial Operational Program for Human Resources Development 2007-2013, co-financed by the European Social Fund, under the project number POSDRU/159/1.5/S/132400 with the title, Young successful researchers - professional development in an international and interdisciplinary environment". Warmly thanked for field work support are Mrs. Zhulieta Misha and Mr. Arqile Pallko from Albanian Geological Survey. We kindly thank the reviewers Michael Wagreich and Ramona Bălc for their comments and suggestions, which significantly improved the quality of this manuscript.

\section{REFERENCES}

Agnini, C., Fornaciari, E., Raffi, I., Catanzariti, R., Pälike, H., Backman, J. \& Rio, D. 2014, Biozonation and biochronology of Paleogene calcareous nannofossils from low and middle latitudes. Newsletters on Stratigraphy, 47 (2): 131-181. http://dx.doi.org/10.1127/0078-0421/2014/0042 
Aubry, M.-P. 1992, Late Paleogene calcareous nannoplankton evolution: a tale of climatic deterioration. In: EoceneOligocene climatic and biotic evolution (Prothero, D.R., Berggren, W.A., Eds.). Princeton University Press, p. 272309. http://dx.doi.org/10.1515/9781400862924.272

Aubry, M.-P., Villa, G. 1996, Calcareous nannofossil stratigraphy of the Lemme-Carrosio Paleogene/Neogene Global Stratotype Section and Point. Giornale di Geologia, 58 (1-2): 51-69.

Berggren, W.A., Kent, D.V., Swisher, C.C. \& Aubry, M.P. 1995, A revised Cenozoic geochronology and chronostratigraphy. Society of Economics Paleontologists and Mineralogists Special Publication, 54: 129-212. http://dx.doi.org/10.2110/pec.95.04.0129

Bizon, G., Müller, C. 1979, Remarks on the Oligocene/ Miocene boundary based on the results obtained from the Pacific and the Indian Oceans. Annales Géologiques des Pays Helléniques, 1: 101-111. http://dx.doi.org/10.2973/dsdp.proc.42-1.142.1978

Bourcart, J. 1922, Les confines albanais administres par la France (1916-1920). Contribution à la Géographie et à la Géologie de l'Albanie moyenne. Librairie Delagrave, Paris, p. 265.

Bourcart, J. 1925, Observation nouvelles sur la téctonique de l'Albanie moyenne. Bulletin de la Société Géologique de France, Paris, 25: 391-428.

Bown, P.R., Young, J.R. 1998, Techniques. In: Calcareous nannofossil biostratigraphy (Bown, P.R., Ed.). Kluwer Academic Publications, Dordrecht, p. 16-28. http://dx.doi.org/10.1007/978-94-011-4902-0 2

Brunn, J.H. 1956, Contribution à l'étude géologique du Pinde Septentrionale et d'une partie de la Macédoine Occidentale. Annales Geologiques des Pays Helleniques, Athens, 1 serie, VII, 358 p.

Bukry, D., Douglas, R.G, Kling, S.A. \& Krasheninnikov V. 1971, Planktonic microfossil biostratigraphy of the northwestern Pacific Ocean. In: Initial Reports of the Deep Sea Drilling Project (Fischer, A.G., Heezen, B.C., Boyce, R.E., Bukry, D., Douglas, R.G., Garrison, R.E., Kling, S.A., Krasheninnikov, V., Lisitzin, A.P., Pimm, A.C., Eds.), 6: 1253-1300.

http://dx.doi.org/10.2973/dsdp.proc.6.139.1971

Çobo, L. 1986, Biostratigraphy of the Tortonian - Messinian deposits in Divjakë, Ardenicë, Frakull and Seman regions, based on calcareous nannofossils. Fondi $i$ Institutit Gjeologik të Naftës, Fier (in Albanian).

Çobo, L. 1992, Biostratigraphy of the Burdigalian - Langhian - Serravalian - Tortonian deposits of Ionian Zone and UPA, in Albania, based on calcareous nannofossils. Fondi i Institutit Gjeologik të Naftës, Fier (in Albanian).

Çobo, L. 1996, Evolution of the results achieved on calcareous nannofossils study, on Miocene deposits from our country. Nafta Shqiptare, 2: 81-85 (in Albanian).

Ćorić, S., Rögl, F. 2004, Roggendorf-1 borehole, a key section for Lower Badenian transgressions and the stratigraphic position of the Grund Formation. Geologica Carpathica, 55 (2): 165-178.
Ćorić, S., Hohennegger, J. 2008, Quantitative analyses of calcareous nannoplankton assemblages from the BadenSooss section (Middle Miocene of Vienna Basin, Austria). Geologica Carpathica, 59 (5): 447-460.

Dalipi, V., Çobo, L. 1989, Biostratigraphy and paleogeography of Tortonian - Messinian deposits, based on microfauna and calcareous nannofossils from UPA. Fondi $i$ Institutit Gjeologik të Naftës, Fier (in Albanian).

Davis, J.C. 1986, Statistics and Data Analysis in Geology ( $2^{\text {nd }}$ ed.). John Wiley \& Sons, $646 \mathrm{p}$

Fornaciari, E., Raffi, I., Rio, D., Villa, G., Backman, J. \& Olafsson, G. 1990, Quantitative distribution patterns Oligocene and Miocene calcareous nannofossils from the western equatorial Indian Ocean. In: Proceedings of the Ocean Drilling Program, Scientific Results (Duncan, R.A., Backman, J., Peterson, L.C., Eds.), College Station, TX, 115: 237-254.

http://dx.doi.org/10.2973/odp.proc.sr.115.153.1990

Fornaciari, E., Rio, D. 1996, Latest Oligocene to early middle Miocene quantitative calcareous nannofossilbiostratigraphy in the Mediterranean region. Micropaleontology, 42 (1): 1-36. http://dx.doi.org/10.2307/1485981

Gartner, S., Chen, M.P. \& Stanton, R.J. 1983, Late Neogene nanofossil biostratigraphy and paleoceanography of the northeastern Gulf of Mexico and adjacent areas. Marine Micropaleontology, 8 (1): 17-50. http://dx.doi.org/10.1016/0377-8398(83)90003-8

Haq, B.U. 1980, Biogeographic history of Miocene calcareous nannoplankton and paleoceanography of the Atlantic Ocean. Micropaleontology, 26 (4): 414-443. http://dx.doi.org/10.2307/1485353

Hammer, Ø., Harper, D.A.T. \& Ryan, P.D. 2001, PAST: Paleontological statistics software package for education and data analysis. Palaeontologia Electronica, 4 (1): 1-9.

Harper, D.A.T. 1999, Numerical Palaeobiology: computerbased modelling and analysis of fossils and their distribution. John Wiley \& Sons, 468 p.

Holcová, K. 2005, Quantitative calcareous nannoplankton biostratigraphy of the Oligocene/Miocene boundary interval in the northern part of the Buda Basin (Central Paratethys). Geological Quarterly, 49 (3): 263-274.

Islami, Xh., Prençi, J. 1983, On the separation of the Middle Miocene deposits by the mean of calcareous nannofossils in some outcrops and drills in UPA. Fondi $i$ Institutit Gjeologik të Naftës, Fier (in Albanian).

Islami, Xh., Çobo, L. 1985, Ongoing investigation on Tortonian - Mesinnian deposits from some outcrops from UPA, based on calcareous nannofossils. Fondi i Institutit Gjeologik të Naftës, Fier (in Albanian).

Kameo, K. 2002, Late Pliocene Caribbean surface water dynamics and climatic changes based on calcareous nannofossil records. Palaeogeography, Palaeoclimatology, Palaeoecology, 179 (3-4): 211-226. http://dx.doi.org/10.1016/s0031-0182(01)00432-1

Kleinholter, K. 2004, Palaogene Pflanzenfossilien aus dem Korca-becken, Sudost-Albanien. Münstersche Forschungen zur Geologie und Paläontologie, 99: 111-118. 
Krhovský J., Adamová J., Hladíková J. \& Maslowská H. 1992: Paleoenvironmental changes across the Eocene/ Oligocene boundary in the Ždánice and Pouzdřany Units (Western Carpathians, Czechoslovakia): The long-term trend and orbitally forced changes in calcareous nannofossil assemblages. In: Proceedings of Fourth INA Conference (Hamršmíd, B., Young, J.R., Eds). Nannoplankton Research, Prague, 1991, Knihovnička Zemní Plyn Nafta, $14 b$ (2): 105-187.

Krhovský, J., Bubík, M., Hamršmíd, B. \& Š_Astný, M. 1995, Lower Miocene of the Pouzdøany Unit, the West Carpathian Flysch belt, Southern Moravia. Knihovnièka Zemni Plyn Nafta, 16: 73-83.

Kumati, L1., Korroveshi, T., Myftari, S., Vathi, K., Marku, D., Sadushi, P., Gjani, E., Dulaj, A., Shtrepi, P., Seiti, E., Veizaj, V., Zaka, M. \& Polo, S. 1997, Study on the structure, biostratigraphy, depositional environment and geochemical potential of the internal basins of the Albanian-Mesohellenik Despression in Burrel-KorçaGreece region. Instituti $i$ Studimeve dhe i Projektimeve Gjeologjike te Naftës dhe Gazit, Fier (in Albanian).

Lohman, G.P., Carlson, J.J. 1981, Oceanographic significance of Pacific late Miocene calcareous nannoplankton. Marine Micropaleontology, 6: 553-579. http://dx.doi.org/10.1016/0377-8398(81)90021-9

Marku, D. 2000, Biostratigraphy and depositional environments of molasse deposits in Korça reagion, based on macrofossils. Shërbimi Gjeologjik Shqiptar, Tirana (in Albanian)

Martini, E. 1971, Standard Tertiary and Quaternary calcareous nannoplankton zonations. In: Proceedings $2^{\text {nd }}$ International Conference on Planktonic Microfossils Roma 1970 (Farinacci, A., Ed.). Edizioni Tecnoscienza, Roma, 2: 739-785.

Martini, E. 1981, Nannoplankton in der Ober-Kreide, im Alttertiàr und im tieferen Jungtertiàr von Süddeutschland und dem angrenzenden österreich. Geologia Bavarica, 82: 345-356.

Martini, E., Müller, C., 1975, Calcareous nannoplankton from the type Chattian (Upper Oligocene). 6th Congress Regional Committee on Mediterranean Neogene Stratigraphy, Bratislava, 1: 37-41.

Mărunţeanu, M. 1992, Distribution of the Miocene calcareous nannofossils in the Intra- and Extra-Carpathian areas of Romania. Knihovnièka Zemni Plyn Nafta, 14b (2): 247262.

Meço, S., Aliaj, Sh. 2000, Geology of Albania. Schweizerbart Science Publishers, Stuttgart, X, 246 p.

Müller, C. 1976, Tertiary and Quaternary calcareous nannoplankton in the Norwegian-Greenland Sea, DSDP, Leg 38. In: Initial Reports of the Deep Sea Drilling Project (Talwani, M., Udintsev, G., White, S.M., Eds.), p. 823-841. http://dx.doi.org/10.2973/dsdp.proc.38.126.1976

Nagymarosy, A., Voronina, A.A. 1992, Calcareous nannoplankton from the Lower Maikopian beds (Early Oligocene, Union of Independent States). In: Proceedings of Fourth INA Conference (Hamršmíd, B., Young, J.R., Eds.). Nannoplankton Research, Prague, 1991, Knihovnička Zemní Plyn Nafta, 14b (2): 187-221.
Okada, H., McInyre, A. 1979, Seasonal distribution of the modern Coccolithophores in the western North Atlantic Ocean. Marine Biology, 54 (4): 319-328. http://dx.doi.org/10.1007/bf00395438

Okada, H., Bukry, D. 1980, Supplementary modification and introduction of code numbers to the low-latitude coccolith biostratigraphic zonation (Bukry, 1973; 1975). Marine Micropaleontology, 5: 321-325. http://dx.doi.org/10.1016/0377-8398(80)90016-x

Papa, A., Pashko, P. 1966, Early Miocene in Albania. Studime Gjeologjike, 1: 129-149 (in Albanian).

Pashko, P. 1977, Biostratigraphy, mollusks and nomenclature of the Oligocene deposits of Morava. Përmbledhje Studimesh, 3: 63-86 (in Albanian).

Pashko, P. 1981, Paleogeography of the Oligocene deposits of Korça Basin. Përmbledhje Studimesh, 3: 47-61 (in Albanian).

Pashko, P. 1986, The life behavior of Cenozoic organisms and their usefulness in paloegeographical studies. Buletini i Shkencave Gjeologjike, 1: 47-56 (in Albanian).

Pashko, P. 1987, Bentonic organisms and their value for paloegeographical studies. Buletini $i$ Shkencave Gjeologjike, 2: 73-82 (in Albanian).

Pashko, P. 1996, Stratigraphy of the Terciary intramountain basins. In: Neotectonic structure of Albanids and their geodynamic evolution (Aliaj, Sh., Melo, V., Skrami, J., Mehillka, L., Muço, B., Sulstarova, E., Profti, K., Pashko, P., Prillo, S., Eds.). Fakulteti Gjeologji-Miniera, Universiteti Politeknik, Tirana, 497 p. (in Albanian).

Pashko, P., Papa, A., Huta, B. \& Myftari, A. 1973, Stratigraphy of the Paleogene and Neogene deposits from tektonik zone of Mirdita. Archives of Albanian Geological Survey, 564 p. (in Albanian).

Perch-Nielsen, K. 1985, Cenozoic calcareous nannofossils. In: Plankton stratigraphy (Bolli, H.M., Saunders, J.B., Perch-Nielsen, K., Eds). Cambridge University Press, p. 427-554.

Petro, Th., Dodona, E. 1976, Lithofacies and biostratigraphycal importance of the coral horizon in molasses structures of Morava and Gora-Mokra. Përmbledhje Studimesh, Tirana, 3: 29-50 (in Albanian).

Philippson, A., Oppenheim, P. 1894, Tertiär und Tertiärfossilien in Nord-Griechenland, sowie in Albanien unde bei Patrasim Peloponnes. Zeitschrift der deutschen geologischen Gesellschaft, Berlin, 46: 800-822.

Raffi, I. 1999, Precision and accuracy of nannofossil biostratigraphic correlation. Philosophical Transactions of the Royal Society A: Mathematical, Physical and Engineering, 357: 1975-1993. http://dx.doi.org/10.1098/rsta.1999.0410

Rahman, A., Roth, P.H. 1990, Late Neogene paleooceanography and paleoclimatology of the Golf of Aden region based on calcareous nannofossils. Paleooceanography, 5 (1): 91-107. http://dx.doi.org/10.1029/pa005i001p00091

Shackleton, N.J., Hall, M.A., Raffi, I., Tauxe, L. \& Zachos, J. 2000, Astronomical calibration for the Oligocene-Miocene boundary. Geology, Boulder, 28: 447-450. http://dx.doi.org/10.1130/0091-7613(2000)28\%3C447 :acafto\%3E2.0.co;2 
Shcherbinina, E. 2010, Response of early Paleogene nannofossils to periodically increased nutrient availability in the NE Peri-Tethys. EGU General Assembly 2010, Vienna, $13597 \mathrm{p}$.

Tomanová Petrová, P., Švábenická, L. 2006, Lower Badenian biostratigraphy and paleoecology: a case study from the Carpathian Foredeep (Czech Republic). Geologica Carpathica, 58 (4): 333-352.

Vathi, K. 1985, Les nannofossiles calcaires du flysch de la zone ionienne d'Albanie. $\mathrm{PhD}$ Thesis, Mémoire des Sciences de la Terre, Universite Curie, Paris, 85 (19), 124 p.

Vathi, K. 1987, Paleogen/Neogene boundary in south-western Albania (Ionian Zone) based on calcareous nannofossils. Buletini "Nafta dhe Gazi”, 2: 87-95 (in Albanian).

Vathi, K. 1989, Zonation of the flysch in Ionian Zone based on calcareous nannofossils. Buletini "Nafta dhe Gazi", 1: 57-70 (in Albanian).

Vathi, K. 1998, Biostratigraphy of the Oligocene-Miocene flysch deposits from Paper-Rovë based on calcareous nannofossils. Buletini “Nafta Shqiptare”, Fier, p. 54-62 (in Albanian).
Vathi, K., Budri, E. 1986, Biostratigraphycal interpretation of the Late Oligocene-Early Miocene deposits from Ionian Zone (Kurveleshi Area) based on calcareous nannofossils. Fondi i Institutit Gjeologik të Naftës, Fier (in Albanian).

Villa, G., Fioroni, C.L., Pea, L., Bohatý, S. \& Persico, D. 2008, Middle Eocene-late Oligocene climate variability: Calcareous nannofossil response at Kerguelen Plateau, Site 748. Marine Micropaleontology, 69 (2): 173-192. http://dx.doi.org/10.1016/j.marmicro.2008.07.006

Wade, B.S., Bown, P.R. 2006, Calcareous nannofossils in extreme environments: The Messinian Salinity Crisis. Polemi Basin, Cyprus. Palaeogeography, Palaeoclimatology, Palaeoecology, 233: 271-286. http://dx.doi.org/10.1016/j.palaeo.2005.10.007

Winter, A., Jordan, R. \& Roth, P. 1994, Biogeography of living Coccolithophores in ocean waters. In: Coccolithophores (Winter, A., Siesser, W., Eds.). Cambridge University Press, Cambridge, p. 13-37.

Xhomo, A., Kodra, A., Xhafa, Z. \& Shallo, M. 2002, Albanian Geology. Tirana, 435 p. (in Albanian).

Young, J.R. 1998, Neogene. In: Calcareous nannofossil biostratigraphy (Bown, P.R., Ed.). Kluwer Academic Publications, Dordrecht, p. 225-265. http://dx.doi.org/10.1007/978-94-011-4902-08 
PLATE I. Calcareous nannofossils from "Bozdovec Transect" (Albania). Scale bar is 10 $\mu \mathrm{m}$. XPL - cross-polarized light, BF - bright field.

Fig. 1. - Helicosphaera bramlettei (Müller, 1970) Jafar and Martini, 1975 (Sample BD62, XPL);

Fig. 2. - Helicosphaera intermedia Martini, 1965 (Sample BD54, XPL);

Figs. 3-4. - Helicosphaera recta (Haq, 1966) Jafar and Martini, 1975 (Sample BD32, XPL and BF);

Fig. 5. - Helicosphaera obliqua Bramlette and Wilcoxon, 1967 (Sample BD105, XPL);

Fig. 6. - Zygrhablithus bijugatus maximus Bown, 2010 (Sample BD96, XPL);

Fig. 7. - Reticulofenestra scrippsae Bukry and Percival, 1971 (Sample BD86, XPL);

Fig. 8. - a) Sphenolithus moriformis (Bronnimann and Stradner, 1960) Bramlette and Wilcoxon, 1967; b) Zygrhablithus bijugatus (Deflandre in Deflandre and Fert, 1954) Deflandre, 1959 (Sample BD95, XPL);

Fig. 9. - Coccolithus pelagicus (Wallich 1877) Schiller, 1930 (Sample BD95, XPL);

Fig. 10. - Clausicoccus fenestratus (Deflandre and Fert, 1954) Prins, 1979 (Sample BD28, XPL);

Fig. 11. - Coccolithus miopelagicus Bukry, 1971 (Sample BD70, BF);

Fig. 12. - Coccolithus eopelagicus (Bramlette and Riedel, 1954) Bramlette and Sullivan, 1961 (Sample BD23, XPL);

Fig. 13. - Cyclicargolithus abisectus Muller, 1970 (Sample BD89, XPL);

Figs. 14-15. - Triquetrorhabdulus carinatus Martini, 1965 (Sample BD68, XPL and BF);

Fig. 16. - Reticulofenestra sp. small (Sample BD68, XPL);

Fig. 17. - Reticulofenestra dictyoda (Deflandre in Deflandre and Fert, 1954) Stradner in Stradner and Edwards, 1968 (Sample BD63, XPL);

Fig. 18. - Hughesius tasmaniae (Edwards and Perch-Nielsen, 1975) de Kaenel and Villa, 1996 (Sample BD44, XPL);

Fig. 19. - Reticulofenestra minuta Roth, 1970 (Sample BD52, XPL);

Fig. 20. - Reticulofenestra bisecta Hay, Mohler and Wade, 1966 (Sample BD23, XPL);

Fig. 21. - Cyclicargolithus floridanus Roth and Hay, in Hay et al., 1967 (Sample BD96, XPL);

Fig. 22. - Sphenolithus moriformis (Bronnimann and Stradner, 1960) Bramlette and Wilcoxon, 1967;

Figs. 23-24. - Sphenolithus ciperoensis Bramlette and Wilcoxon, 1967 (Sample BD9, $0^{\circ}-45^{\circ}$ XPL);

Fig. 25. - Pontosphaera cf. enormis (Locker, 1967) Perch-Nielsen, 1984 (Sample BD95, XPL);

Fig. 26. - Reticulofenestra sp. small (Sample BD61, XPL);

Figs. 27-28. - Sphenolithus cf. delphix Bukry 1973 (Sample BD64, $0^{\circ}-45^{\circ}$ XPL);

Fig. 29. - Discoaster deflandrei Bramlette and Riedel, 1954 (Sample BD86, BF);

Fig. 30. - Ilselithina fusa Roth, 1970 (Sample BD19, XPL);

Fig. 31. - Rhabdosphaera sp. (Sample BD65, XPL);

Fig. 32. - a) Cyclicargolithus floridanus Roth and Hay, in Hay et al., 1967; b) Helicosphaera perch-nielseniae (Haq, 1971) Jafar and Martini, 1975 (Sample BD26, XPL);

Figs. 33-34. - Sphenolithus cf. delphix Bukry 1973 (Sample BD32, $0^{\circ}-45^{\circ} \mathrm{XPL}$ );

Figs. 35-36. - Sphenolithus conicus Bukry, 1971 (Sample BD48, $0^{\circ}-45^{\circ} \mathrm{XPL}$ ); 
PLATE I
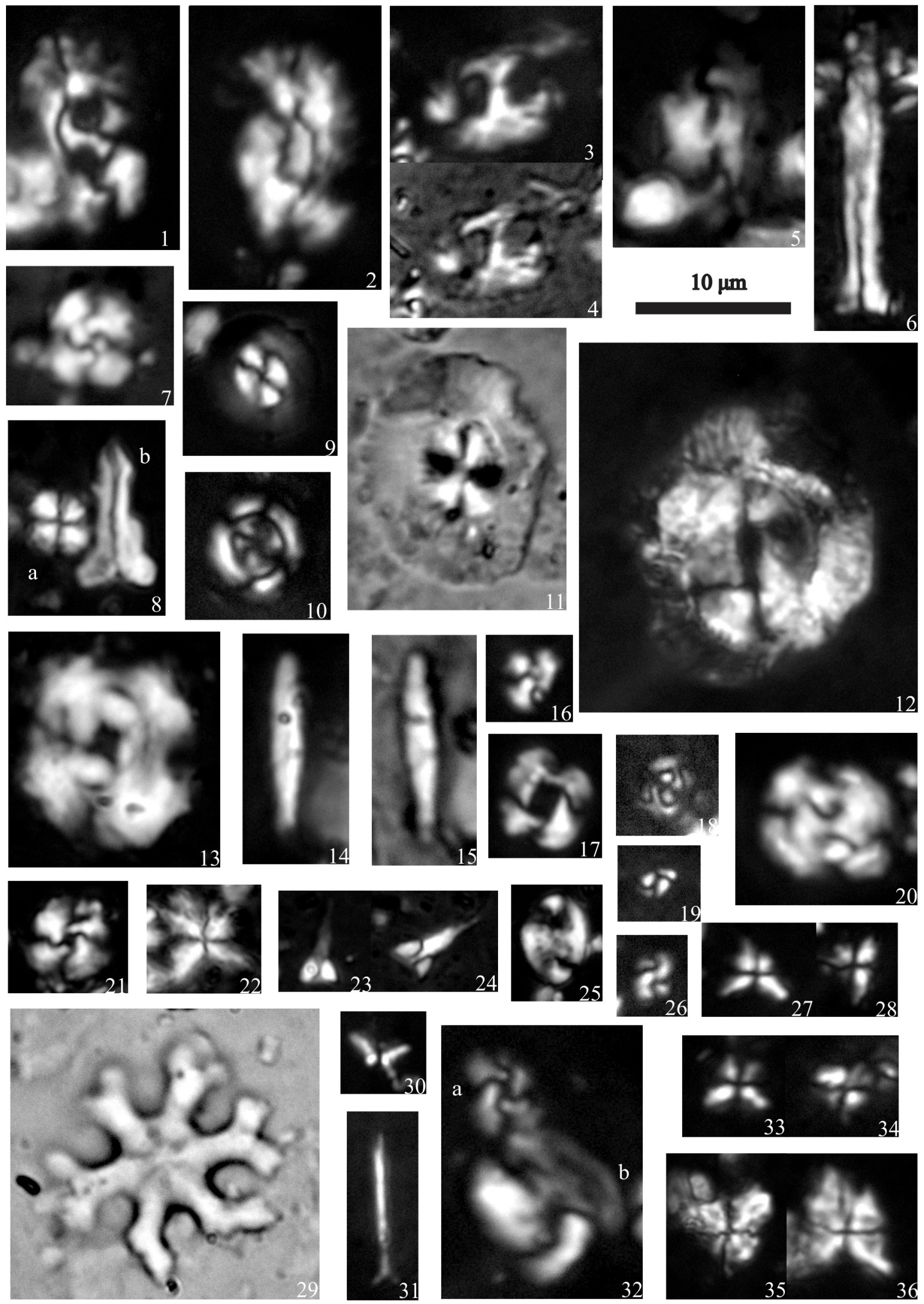
Appendix 1. List of species present in "Bozdovec Transect" (Albanian-Thessalian intramontane basin) arranged in alphabetical order: a) autochthonous calcareous nannofossils; b) reworked calcareous nannofossils from Paleogene - Early Oligocene; c) reworked calcareous nannofossils from Cretaceous.

\begin{tabular}{|c|c|}
\hline & $\begin{array}{l}\text { Number of specimens } \\
\text { / specie }\end{array}$ \\
\hline \multicolumn{2}{|l|}{ a. Autochtonous calcareous nannofossils } \\
\hline Braarudosphaera bigelowii (Gran and Braarud, 1935) Deflandre, 1947 & 6 \\
\hline Calcidiscus sp. Kamptner, 1950 & 61 \\
\hline Clausicoccus fenestratus (Deflandre and Fert, 1954) Prins, 1979 & 183 \\
\hline Clausicoccus subdistichus (Roth and Hay in Hay et al., 1967) Prins, 1979 & 110 \\
\hline Clausicoccus sp. Prins, 1979 & 7 \\
\hline Coccolithus eopelagicus (Bramlette and Riedel, 1954) Bramlette and Sullivan, 1961 & 23 \\
\hline Coccolithus miopelagicus Bukry, 1971 & 83 \\
\hline Coccolithus pelagicus (Wallich 1877) Schiller, 1930 & 2606 \\
\hline Coronocyclus nitescens (Kamptner, 1963) Bramlette and Wilcoxon, 1967 & 15 \\
\hline Coronocyclus sp. Hay, Mohler and Wade, 1966 & 2 \\
\hline Coronosphaera sp. Gaarder in Gaarder \& Heimdal, 1977 & 24 \\
\hline Cyclicargolithus abisectus (Muller, 1970) Wise, 1973 & 539 \\
\hline Cyclicargolithus floridanus (Roth and Hay, in Hay et al., 1967) Bukry, 1971 & 5481 \\
\hline Discoaster adamanteus Bramlette and Wilcoxon, 1967 & 11 \\
\hline Discoaster barbadiensis Tan, 1927 & 10 \\
\hline Discoaster deflandrei Bramlette and Riedel, 1954 & 187 \\
\hline Discoaster $\mathrm{sp}$. Tan, $1927 \mathrm{~b}$ & 84 \\
\hline Helicosphaera carteri (Wallich 1877) Kamptner, 1954 & 12 \\
\hline Helicosphaera euphratis Haq, 1966 & 198 \\
\hline Helicosphaera intermedia Martini, 1965 & 88 \\
\hline Helicosphaera obliqua Bramlette and Wilcoxon, 1967 & 58 \\
\hline Helicosphaera perch-nielseniae (Haq, 1971) Jafar and Martini, 1975 & 53 \\
\hline Helicosphaera recta (Haq, 1966) Jafar and Martini, 1975 & 71 \\
\hline Helicosphaera sp. Kamptner, 1954 & 19 \\
\hline Hughesius tasmaniae (Edwards and Perch-Nielsen, 1975) de Kaenel and Villa, 1996 & 36 \\
\hline Ilselithina fusa Roth, 1970 & 15 \\
\hline Micrantholithus sp. Deflandre in Deflandre and Fert, 1954 & 1 \\
\hline Pontosphaera cf. enormis (Locker, 1967) Perch-Nielsen, 1984 & 31 \\
\hline $\begin{array}{l}\text { Pontosphaera multipora (Kamptner, } 1948 \text { ex Deflandre in Deflandre and Fert, 1954) Roth, } \\
1970\end{array}$ & 45 \\
\hline Pontosphaera sp. Lohmann, 1902 & 16 \\
\hline Pyrocyclus orangensis (Bukry, 1971) Backman, 1980 & 12 \\
\hline Rhabdosphaera sp. Haeckel, 1894 & 5 \\
\hline Reticulofenestra bisecta (Hay, Mohler and Wade, 1966) Roth, 1970 & 413 \\
\hline Reticulofenestra daviesii (Haq, 1968) Haq, 1971 & 31 \\
\hline $\begin{array}{l}\text { Reticulofenestra dictyoda (Deflandre in Deflandre and Fert, 1954) Stradner in Stradner and } \\
\text { Edwards, } 1968\end{array}$ & 217 \\
\hline Reticulofenestra lockeri Müller, 1970 & 20 \\
\hline Reticulofenestra minuta Roth, 1970 & 7074 \\
\hline Reticulofenestra cf. minutula (Gartner, 1967) Haq and Berggren, 1978 & 438 \\
\hline Reticulofenestra scrippsae Bukry and Percival, 1971 & 1357 \\
\hline Reticulofenestra stavensis (Levin and Joerger, 1967) Varol, 1989 & 65 \\
\hline Reticulofenestra sp. 3-4.5 $\mu \mathrm{m}$ Hay, Mohler and Wade, 1966 & 2528 \\
\hline Scyphosphaera sp. Lohmann, 1902 & 1 \\
\hline Sphenolithus cf. calyculus Bukry, 1985 & 44 \\
\hline Sphenolithus ciperoensis Bramlette and Wilcoxon, 1967 & 639 \\
\hline \begin{tabular}{|l|} 
Sphenolithus conicus Bukry, 1971 \\
\end{tabular} & 416 \\
\hline Sphenolithus cf. delphix Bukry 1973 & 19 \\
\hline
\end{tabular}


Appendix 1 (continued)

Sphenolithus dissimilis Bukry and Percival, 1971

Sphenolithus moriformis (Bronnimann and Stradner, 1960) Bramlette and Wilcoxon, 1967

Sphenolithus sp. Deflandre in Grassé, 1952

Syracosphaera sp. Lohmann, 1902

Thoracosphaera heimii (Lohmann 1920) Kamptner 1944

Thoracosphaera sp. Kamptner, 1927

Triquetrorhabdulus carinatus Martini, 1965

Triquetrorhabdulus sp. Martini, 1965

Umbilicosphaera detecta (de Kaenel and Villa, 1996) Young and Bown 2014

Umbilicosphaera edgariae (Bown and Dunkley Jones, 2012) Young and Bown 2014

Umbilicosphaera jordanii Bown, 2005

Umbilicosphaera sp. Lohmann, 1902

Zygrhablithus bijugatus (Deflandre in Deflandre and Fert, 1954) Deflandre, 1959

Zygrhablithus bijugatus maximus Bown, 2010

\begin{tabular}{|r|r|} 
& 201 \\
\hline 1967 & 1722 \\
& 156 \\
\hline & 26 \\
\hline & 28 \\
\hline & 10 \\
\hline & 13 \\
\hline & 4 \\
& 1 \\
\hline & 2 \\
\hline & 1 \\
\hline Total : & 1 \\
\hline Oligocene & 120 \\
\hline
\end{tabular}

\section{b. Reworked calcareous nannofossils from Paleogene - Early Oligocene}

Blackites sp. Hay and Towe, 1962

Campylosphaera eroskayi (Varol, 1989) Bown, 2005

Chiasmolithus bidens (Bramlette and Sullivan, 1961) Hay and Mohler, 1967

Chiasmolithus grandis (Bramlette and Riedel, 1954) Radomski, 1968

Chiasmolithus sp. Hay, Mohler and Wade, 1966

Chiastozigus sp. Gartner, 1968

Coccolithus bownii Jiang and Wise, 2007

Coccolithus crucis Bown, 2005

Coccolithus foraminis Bown, 2005

Coccolithus formosus (Kamptner, 1963) Wise, 1973

Coccolithus latus Bown, 2005

Coccolithus pauxillus Bown, 2010

Craticullithus? cassus (Bown, 2005) Bown, 2010

Cruciplacolithus cruciformis (Hay and Towe, 1962) Roth, 1970

Cruciplacolithus sp. Hay and Mohler in Hay et al., 1967

Discoaster lenticularis Bramlette and Sullivan, 1961

Discoaster mahmoudii Perch-Nielsen, 1981

Discoaster mediosus Bramlette and Sullivan, 1961

Discoaster multiradiatus Bramlette and Riedel, 1954

Ericsonia robusta (Bramlette and Sullivan, 1961) Edwards and Perch-Nielsen, 1975

Ericsonia sp. Black, 1964

Fasciculithus sp. Bramlette and Sullivan, 1961

Hornibrookina sp. Edwards, 1973

Isthmolithus recurvus Deflandre in Deflandre and Fert, 1954

Micrantholithus minimus Bown and Dunkley Jones, 2006

Neococcolithes dubius (Deflandre in Deflandre and Fert, 1954) Black, 1967

Pontosphaera rimosa (Bramlette and Sullivan, 1961) Roth and Thierstein, 1972

Prinsius dimorphosus (Perch-Nielsen, 1969) Perch-Nielsen, 1977

Prinsius martinii (Perch-Nielsen, 1969) Haq, 1971

Prinsius sp. Hay and Mohler, 1967

Pseudotriquetrorhabdulus inversus (Bukry and Bramlette, 1969) Wise and Constans,

in Wise 1983

Reticulofenestra reticulata (Gartner and Smith, 1967) Roth and Thierstein, 1972

Reticulofenestra umbilicus (Levin, 1965) Martini and Ritzkowski, 1968

Reticulofenestra wadeae Bown, 2005

Rhabdosphaera gracilentus (Bown and Dunkley Jones, 2006) Dunkley Jones et al., 2009

Rhabdosphaera vitrea (Deflandre in Deflandre and Fert, 1954) Bramlette and Sullivan, 1961

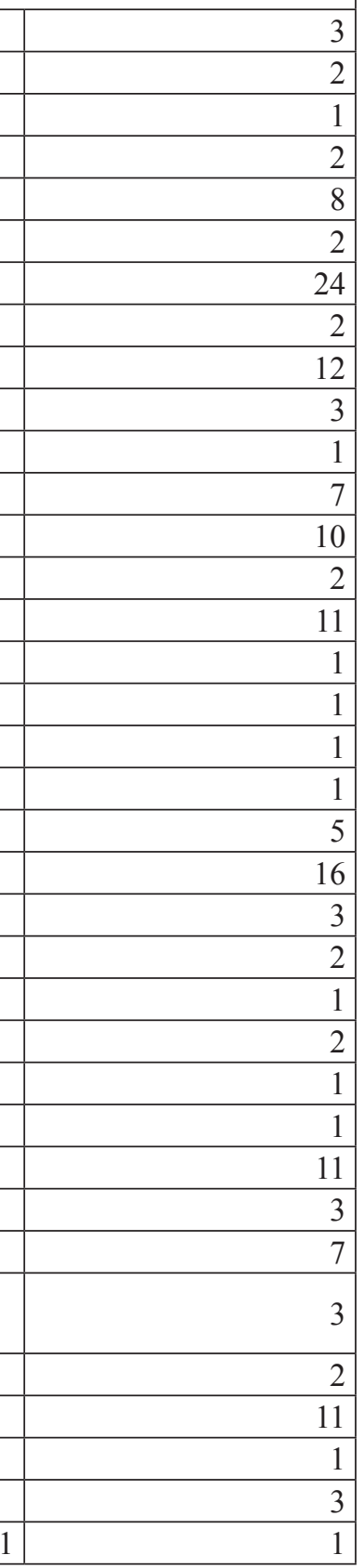




\section{Appendix 1 (continued)}

\begin{tabular}{|c|c|}
\hline Sphenolithus pseudoradians Bramlette and Wilcoxon, 1967 & 1 \\
\hline Sphenolithus radians Delfandre in Grassé, 1952 & 11 \\
\hline Syracosphaera tanzanensis Bown, 2005 & 1 \\
\hline Toweius callosus Perch-Nielsen, 1971 & 11 \\
\hline Toweius pertusus (Sullivan, 1965) Romein, 1979 & 6 \\
\hline Toweius rotundus Perch-Nielsen in Perch-Nielsen et al., 1978 & 34 \\
\hline Toweius selandianus Perch-Nielsen, 1979 & 14 \\
\hline Toweius sp. Hay and Mohler, 1967 & 3 \\
\hline Total : & 248 \\
\hline \multicolumn{2}{|l|}{ c. Reworked calcareous nannofossils from Cretaceous } \\
\hline Arkhangelskiella cymbiformis Vekshina, 1959 & 12 \\
\hline Calculites anfractus (Jakubowski, 1986) Varol and Jakubowski, 1989 & 5 \\
\hline Calculites obscurus (Deflandre, 1959) Prins and Sissingh in Sissingh, 1977 & 2 \\
\hline Calculites sp. Prins and Sissingh in Sissingh, 1977 & 8 \\
\hline Cretarhabdus sp. Bramlette and Martini, 1964 & 6 \\
\hline Cribrosphaerella ehrenbergii (Arkhangelsky, 1912) Deflandre in Piveteau, 1952 & 9 \\
\hline Eiffellithus gorkae Reinhardt, 1965 & 2 \\
\hline Eiffellithus sp. Reinhardt, 1965 & 5 \\
\hline Helicolithus compactus (Bukry, 1969) Varol and Girgis, 1994 & 2 \\
\hline Lithraphidites sp. Deflandre, 1963 & 1 \\
\hline Markalius inversus (Deflandre in Deflandre and Fert, 1954) Bramlette and Martini, 1964 & 4 \\
\hline Markalius sp. Bramlette and Martini, 1964 & 1 \\
\hline Microrhabdulus sp. Deflandre, 1959 & 4 \\
\hline Micula staurophora Gardet, 1955 & 11 \\
\hline Micula sp. Vekshina, 1959 & 9 \\
\hline Prediscosphaera sp. Vekshina, 1959 & 10 \\
\hline Retecapsa sp. Black, 1971a & 3 \\
\hline Uniplanarius gothicus (Deflandre, 1959) Hattner and Wise, 1980 & 1 \\
\hline Uniplanarius sissinghii (Perch-Nielsen, 1986) Farhan, 1987 & 1 \\
\hline Quadrum gartneri Prins and Perch-Nielsen in Manivit et al., 1977 & 1 \\
\hline Quadrum sp. Prins and Perch-Nielsen in Manivit et al., 1977 & 4 \\
\hline Watznaueria barnesiae (Black in Black and Barnes, 1959) Perch-Nielsen, 1968 & 87 \\
\hline Watznaueria sp. Reinhardt, 1964 & 67 \\
\hline Total : & 255 \\
\hline Total all species: & 26.155 \\
\hline
\end{tabular}

